\title{
6. 小児の慢性血液透析導入
}

\section{1 ）透析導入の準備}

のステートメント 9 GFR が $60 \mathrm{~mL} / \mathrm{min} / 1.73$ m前後に低下したら, 保存期腎不全治療に精通した小肾腎 臓専門医へコンサルトすることが望ましい(2D).

○ステートメント 10 GFR が $30 \mathrm{~mL} / \mathrm{min} / 1.73 \mathrm{~m}^{2}$ 前後に低下したら, 腎代替療法 (RRT) に精通した小児 腎臓専門医へコンサルトすることが望ましい(2D).

○ステートメント 11 血液透析を選択した場合は, バスキュラーアクセス (VA) に関わるインフォームド・ コンセントを行い, VA の選択と作製時期に関して十分に検討することが望ましい（2D）.

\section{解 説}

小児 CKD 治療のポイントは, (1) 腎不全の進行抑制, (2) 小児に特徵的な合併症である成長障害の軽減, (3) 生命予 後に深く関わる心血管疾患（CVD）の合併予防，そして (4)生涯にわたる腎不全治療計画を立てることである.

GFR が $60 \mathrm{~mL} / \mathrm{min} / 1.73 \mathrm{~m}^{2}$ を下回ると成長障害が明らかになってくるが， その病態には，骨・ミネラル代謝異 常（mineral and bone disorder：MBD), 原疾患, 腎不全発症年齢, エネルギー摂取不良, 蛋白質・アミノ酸代謝異 常, 代謝性アシドーシス, 電解質異常, 貧血, そして内分泌系異常（とくに成長ホルモン一成長因子系）などの多 くの要因が関与している ${ }^{1}$ ，そのため，小児腎臟専門医による成長障害（低身長）に対する適正な診断と，成長障害 をきたす上記の各要因に対するきめ細かな治療が必要となる.

また, CKD ステージ 2 の早期時点から血清カルシトリオール濃度の低下が始まり, 引き続いて線維芽細胞成長因 子 23 (FGF23)，そして副甲状腺ホルモンが上昇し始めるとされる2). さらに, GFR が $30 \mathrm{~mL} / \mathrm{min} / 1.73 \mathrm{~m}^{2}$ を下回 ると血清リン濃度は上昇し始め ${ }^{2)}$, 代謝性アシドーシスも顕著になってくる ${ }^{3)}$. CKD 患者でみられるリン・カルシ ウムなどの異常を骨病変との関連のみでとらえるのではなく血管石灰化や生命予後と関連した病態として認識する との CKD-MBD の概念は, 成人と同様に小児にもよくあてはまる. 実際, 小児領域でも, 心血管系の石灰化に関連 する因子として, 高カルシウム血症, 高リン血症, 二次性副甲状腺機能充進症などの関与が示され, カルシウム,

リン，副甲状腺ホルモン (parathyroid hormone : PTH) などの適正なコントロールは, CKD-MBD の予防・治療の みならず, CVD 合併予防の点からも重要なことが明らかにされている ${ }^{4 \sim 6)}$ そそのため CKD ステージの早い段階か らの小児腎臓専門医による適正な CKD-MBD 治療が必要である7).

実際，CKD ステージ 2 4 の小児を腎代替療法開始時まで腎不全治療に精通した小児腎臓専門医がフォローした 場合には, 残存腎機能の保持, 血清リン值, 血清カルシウム・リン積值, 血清 PTH 值, 血清へモグロビン值, そし て緊急透析導入の頻度の点でコントロールが有意に優れていたことが報告されている゙ ${ }^{8)}$. しかし実情は, GFRが 20 $\mathrm{mL} / \mathrm{min} / 1.73 \mathrm{~m}^{2}$ 以上の段階で専門医へ紹介されたのはわずか $41 \%$ にずず, 紹介された患者の $31 \%$ は紹介後 1 か 月以内に RRT を開始せざるを得なかったとの報告もあり ${ }^{9)}$, 小児腎臓専門医へのコンサルトが遅くなりがちなのが 現状である.

RRT 開始前には，小児に特有ないくつかの準備すべき事項があるため, GFR が $30 \mathrm{~mL} / \mathrm{min} / 1.73 \mathrm{~m}$ 前後に低下 し, 将来末期腎不全への進行が避けられないと判断された時期に, 腹膜透析, 血液透析, 腎移植のすべてに精通し た小児腎臓専門医ヘコンサルトする ${ }^{10)}$. 腎移植の場合には, 生ワクチン（麻しん, 水痘, 風しん, おたふくかぜ), $\mathrm{B}$ 型肝炎ワクチン, 肺炎球菌ワクチンなどのワクチン接種を済ませておく必要がある。また下部尿路障害を有する 症例の場合には膀胱拡大術などの尿路再建術を, 膀胱尿管逆流を認め移植後に尿路感染の危険性が高い場合には逆 流を認める腎臟を移植前に摘出しておく必要がある ${ }^{10}$. また先行的腎移植が実施可能かどうかについても十分に検 討する必要があり，先行的腎移植に関する本人と家族の理解や生体ドナーの適正な評価に時間を要する ${ }^{10)}$. 腹膜透 
析の場合には, 例えば胃瘦造設術などは腹膜透析導入前に実施しておく必要がある ${ }^{10)}$.

腹膜透析，血液透析，腎移植の三種類の RRT に関して，患者本人や家族に対して，それぞれの利点，欠点を偏向 なく説明し，十分な理解を得た後に，RRT を選択する，それぞれの治療方法に絶対的な禁忌がなければ，患児の希 望, 家族の希望, 介助者の有無なども考慮して選択することになる。腎以外の重篤な併発症・合併症など, 患児の 状態によってはRRT を導入しない選択もあり, 日本透析医学会慢性血液透析療法の導入と終末期患者に対する見 合わせに関する提言（案）に準じて対応する ${ }^{11}$.

血液透析を選択した場合には，VA 作成についての検討が重要である ${ }^{12}$. 血液透析が長期間（目安として 1 年以 上)に及ぶことが予想される場合には自己血管使用皮下動静脈瘦 (arteriovenous fistula：AVF) 作製が望ましい ${ }^{12,13)}$. しかし，熟練したアクセス外科医がいない場合には，血管が細くAVF 作製が難しい小児には勧められない. 無理 にAVF 作製にこだわり血管を荒廃させ，成長して血液透析が必要となった際にAVF 作製に難渋するような状態 は避けなければならない，なお，AVF作製において $2.5 \mathrm{~mm}$ 以上の血管径は必要とされておりり，また AVF作製 に際しての体格の目安は体重 $20 \mathrm{~kg}$ 程度以上とされている ${ }^{15)}$. AVF が発達するには数か月〜半年を要する場合も 多いため, 十分な時間的余裕をもった治療計画が必要である ${ }^{12)}$.また, AVFを作製すると決めた場合には, AVF 側の血管を温存するなどの配虑も必要である，一方，体重 $20 \mathrm{~kg}$ 未満の小监や四肢拘縮・骨格変形などの合併症の ために AVF 作製が困難な小児の血液透析では，カフ型カテーテルを使用することになる ${ }^{12,15)}$ 。 カテーテルを使用 した血液透析を実施する場合には, 右内頸静脈の開存を確認しておくこと, また, 腹膜透析への変更の可能性や今 後の腎移植の実施予定をあらかじめ決めておくなど総合的な治療計画が必要である ${ }^{12)}$.また，将来の AVF 作製や 腎移植を考虑して, 鎖骨下静脈や大腿静脈へのカテーテル挿入は可能な限り避けるのが望ましい ${ }^{12}$. カフ型カテー テル留置術の手順と留意点については, 2011 年版社団法人日本透析医学会「慢性血液透析用バスキュラーアクセス の作製および修復に関するガイドライン」目)を参照していただきたい。なお，カテーテルを使用した血液透析では, カテーテル関連感染症, カテーテルのねじれ (kinking), 血栓症, 静脈損傷 (閉塞) が問題となり, 一方, 最大の利 点は，穿刺への恐怖や痛みがないことである.

\section{2 ) 透析導入のタイミング}

○ステートメント 12 保存的治療に抵抗性の腎不全症候（小児の場合は成長障害も加わる）が出現した場 合, 透析導入を考慮する (2D).

○ステートメント 13 無症候であっても目安として GFR が $10 \mathrm{~mL} / \mathrm{min} / 1.73 \mathrm{~m}^{2}$ 末満に低下したら, 透析 導入を考慮する (2D).

\section{解 説}

エビデンスに基づいた明確な透析導入基準はない. NKFKDOQI ガイドラインでは, GFR が $15 \mathrm{~mL} / \mathrm{min} / 1.73$ $\mathrm{m}^{2}$ 以上の場合でも保存的治療でコントロール困難な腎不全症候が出現した場合には透析を開始するとされてい る ${ }^{15)}$. 実際, オランダとベルギーからのデータによれば, 2007 年 9 月〜 2010 年 12 月の期間中に RRT が開始された 症例のうち $22 \%$ の症例に扔いて, GFR が $15 \mathrm{~mL} / \mathrm{min} / 1.73 \mathrm{~m}^{2}$ 以上の状態で RRT が開始されていた ${ }^{17)}$ ささらに, 透 析導入後の高血圧や肺水腫による入院率を導入時の GFR 值で比較（GFR が $15 \mathrm{~mL} / \mathrm{min} / 1.73 \mathrm{~m}^{2}$ より高值群と 15 $\mathrm{mL} / \mathrm{min} / 1.73 \mathrm{~m}^{2}$ 以下群）した小児例での検討では, GFR 高值導入群のほうが透析導入後の入院のリスクが低かっ たとされている ${ }^{18)}$. このように明確な透析導入基準はないのが現状であるため, 現時点では, 保存的治療に抵抗性 の腎不全症候（代謝性アシドーシス, 高カリウム血症, 低カルシウム血症, 高リン血症, 高血圧, 溢水症状, 腎性 骨異栄養症, 吐気・嘔吐, 食欲低下, 低栄養, そして成長障害など）が出現した場合や, 日常生活の障害程度（通 園・通学困難など）を総合的に評価して透析導入を決めるのが適当と思われる.

一方, 無症候でも GFR が $6 \mathrm{~mL} / \mathrm{min} / 1.73 \mathrm{~m}^{2}$ 未满となる前に透析導入するのがよいとのガイドラインがある ${ }^{19,20)}$. 
また，透析導入が遅れないように，GFR が 8 10 mL/min/ $1.73 \mathrm{~m}^{2}$ の時点で透析導入を考虑すべきとするガイドラ インもある ${ }^{21)}$ ．小児末期腎不全の原因疾患のなかで最も頻度が高い低・異形成腎症例を対象とした RRT 開始時期 を後方視的な検討によれば, GFR が $10 \mathrm{~mL} / \mathrm{min} / 1.73 \mathrm{~m}^{2}$ 未満に進行しても血清カリウム值, リン值, 重炭酸イオン 濃度は比較的良好に保たれ，かつ無症候ではあったものの，急性上気道炎や胃腸炎を契機に緊急透析導入を余儀な くされた症例が少なからず認められた ${ }^{22)}$ ，そのため, 小児の場合には, 無症候であっても目安として GFR が $10 \mathrm{~mL} /$ $\mathrm{min} / 1.73 \mathrm{~m}^{2}$ 未満に進行したら透析導入を考慮するのが安全と思われる．しかし，明らかな腎不全症候を呈さずに 適切に管理されている症例において，腎機能の観点のみから導入基準を設定する医学的根拠は不十分であり，今後 さらに検討が必要な事項である。

\section{文献検索}

検索は, PubMed（キーワード : Children, Adolescent, Hemodialysis, Initiation, Glomerular filtration rate) に て 2005 年 1 月から 2012 年 11 月の期間で検索した。検索した文献のなかから, 総説, 症例報告を除いた観察研究な らびに介入研究を選択し，さらにハンドサーチを行って選択した文献を担当委員が協議のうえ採択した。

アブストラクトテーブル

\begin{tabular}{|c|c|c|c|c|c|}
\hline $\begin{array}{l}\text { 文 } \\
\text { 献 } \\
\text { 番 }\end{array}$ & $\begin{array}{l}\text { 著者 } \\
\text { 雑誌 } \\
\text { 発行年 }\end{array}$ & 対象 & 方法 & 結果 & 結論 \\
\hline 4 & $\begin{array}{l}\text { Goodman WG } \\
\text { N Engl J Med } \\
2000\end{array}$ & $\begin{array}{l}39 \text { 名の透析患者 [年齢 } \\
19 \pm 7 \text { 歳 }(7 \text { 歳 })] \text { と } \\
60 \text { 名の健常人 }(20 \sim 30 \\
\text { 歳) }\end{array}$ & $\begin{array}{l}\mathrm{CT} \text { で冠動脈石灰化の程 } \\
\text { 度と臨床所見, 血清 Ca, } \\
\mathrm{P} \text { その他の生化学指標と } \\
\text { の関連を検討 }\end{array}$ & 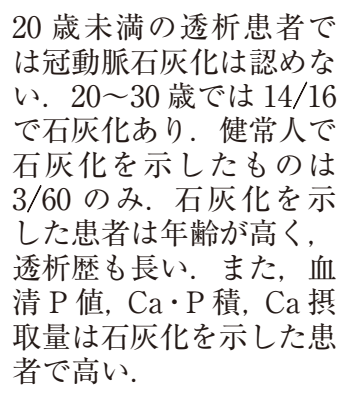 & $\begin{array}{l}\text { 若年成人の透析患 } \\
\text { 者では冠動脈石灰 } \\
\text { 化はよくみられ } \\
\text { る. }\end{array}$ \\
\hline 5 & $\begin{array}{l}\text { Schroff RC } \\
\text { J Am Soc } \\
\text { Nephrol } \\
2007\end{array}$ & $\begin{array}{l}6 \text { か月以上透析を継続し } \\
\text { ている } 5 \text { 18 歳の小児 } \\
85 \text { 名. } \\
\text { 対照群:年齢, 性別をマッ } \\
\text { チさせた健常小児 } 40 \text { 名 }\end{array}$ & $\begin{array}{l}\text { 頸動脈 intima-meda 厚 } \\
\text { (内膜中膜複合体厚), 脈 } \\
\text { 波伝播速度 (PWV), 心 } \\
\text { 臓 CT での石灰化スコア } \\
\text { を比較 }\end{array}$ & 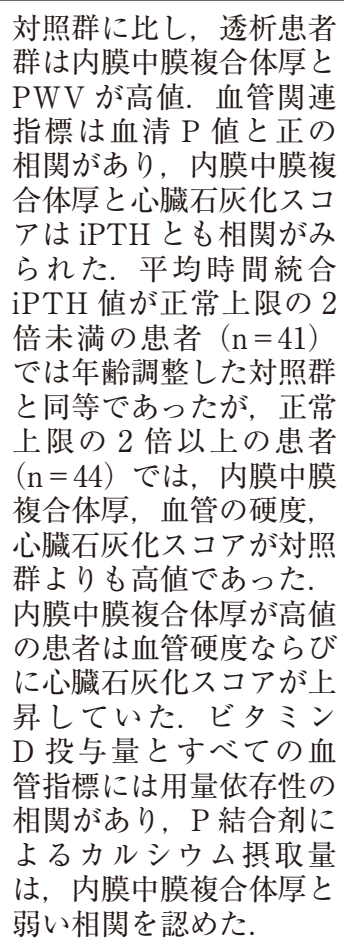 & $\begin{array}{l}\text { 小児透析患者で } \\
\text { は, iPTHとビ夕 } \\
\text { ミン D 投与量は } \\
\text { 血管傷害と石灰化 } \\
\text { に関連を認めた. }\end{array}$ \\
\hline
\end{tabular}




\begin{tabular}{|c|c|c|c|c|c|}
\hline 8 & $\begin{array}{l}\text { Menon S } \\
\text { Clin J Am Soc } \\
\text { Nephrol } \\
2009\end{array}$ & $\begin{array}{l}1996 \text { 年から } 2001 \text { 年の } \\
\text { 間, 通常の腎臓内科クリ } \\
\text { ニックに通院した } 20 \text { 名 } \\
\text { と, } 2002 \text { 年から } 2007 \text { 年 } \\
\text { に透析開始前 } 1 \text { 年間, 多 } \\
\text { 職種による包括的慢性腎 } \\
\text { 臓病クリニックに通院し } \\
\text { ていた } 24 \text { 名 }\end{array}$ & $\begin{array}{l}\text { 診療録を用いた後ろ向き } \\
\text { 観察研究. } \\
\text { 透析開始時の検査值, 成 } \\
\text { 長, 透析アクセスのタイ } \\
\text { プを比較する. }\end{array}$ & 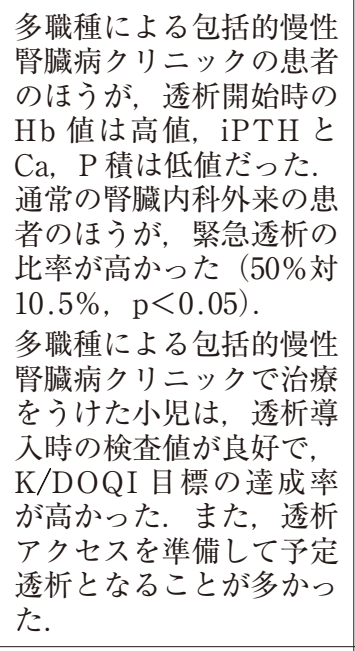 & $\begin{array}{l}\text { 多職種による包括 } \\
\text { 的慢性腎臓病クリ } \\
\text { ニックが有効であ } \\
\text { る. }\end{array}$ \\
\hline 9 & $\begin{array}{l}\text { van Stralen KJ } \\
\text { Nephrol Dial } \\
\text { Transplant } \\
2010\end{array}$ & $\begin{array}{l}\text { ESPN/ERA-EDTA レ } \\
\text { ジストリの } 14 \text { か 国, } \\
2002 \text { 年から } 2007 \text { 年の間 } \\
\text { に, 新規透析導入となっ } \\
\text { た } 18 \text { 歳未満の患者 } 938 \\
\text { 名 }\end{array}$ & $\begin{array}{l}\text { Schwartz 式から eGFR } \\
\text { を計算. 年齢, 性別, 治 } \\
\text { 療法, 原疾患, 地域で調 } \\
\text { 整 }\end{array}$ & 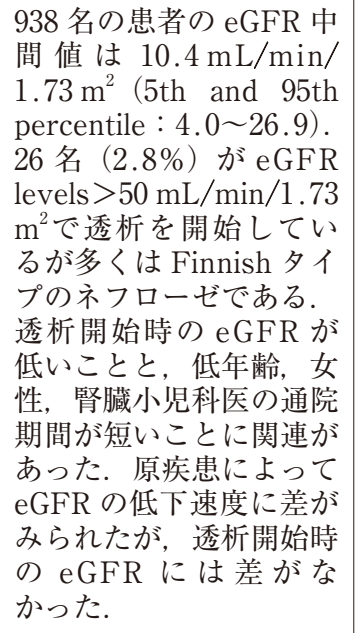 & $\begin{array}{l}\text { 腎代替療法開始時 } \\
\text { の eGFR を決定 } \\
\text { する主要因子は年 } \\
\text { 齢, 性別, 開始時 } \\
\text { 治療法だった. }\end{array}$ \\
\hline 13 & $\begin{array}{l}\text { Zaritsky JJ } \\
\text { Pediatr Neph- } \\
\text { rol } \\
2008\end{array}$ & $\begin{array}{l}2 \text { つの小児透析施設で維 } \\
\text { 持透析を } 3 \text { か月以上継続 } \\
\text { してい } 25 \text { 歳未満, 体 } \\
\text { 重 } 20 \mathrm{~kg} \text { 以上の小児 }\end{array}$ & $\begin{array}{l}\text { 診療録をもとにした後ろ } \\
\text { 向き観察研究. 透析アク } \\
\text { セス関連合併症ならびに } \\
\text { 健康関連 QOL }(\mathrm{HRQOL}) \\
\text { を比較した. }\end{array}$ & 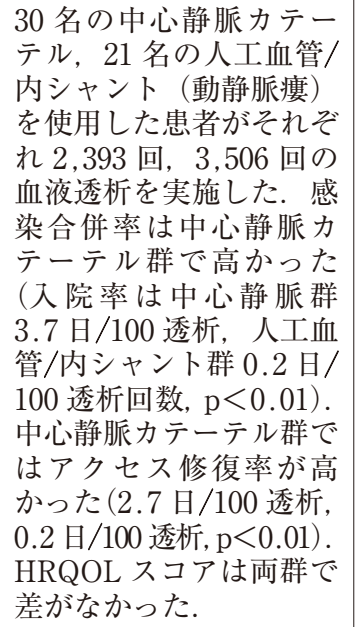 & $\begin{array}{l}\text { 長期維持透析が予 } \\
\text { 想される小览で } \\
\text { は, 人工血管/内 } \\
\text { シャンを血液透 } \\
\text { 析アクセスの第一 } \\
\text { 選択とすべきであ } \\
\text { る. }\end{array}$ \\
\hline
\end{tabular}




\begin{tabular}{|c|c|c|c|c|c|}
\hline 14 & $\begin{array}{l}\text { Gradman WS } \\
\text { Ann Vasc Surg } \\
2005\end{array}$ & $\begin{array}{l}1999 \text { 年 } 3 \text { 月から } 2004 \text { 年 } \\
4 \text { 月の間に自己血管を用 } \\
\text { いた透析アクセスを作製 } \\
\text { した } 47 \text { 名の小児. 女性 } \\
16 \text { 名, 男性 } 31 \text { 名, 平均 } \\
\text { 年齢は } 14.6 \text { 歳（レンジ } \\
5 \text { 20) }\end{array}$ & $\begin{array}{l}\text { DOQI ガイドラインは自 } \\
\text { 家透析アクセス作製を推 } \\
\text { 奨しているが小児では困 } \\
\text { 難である.診療録を用い } \\
\text { て後ろ向きに現状を総括 } \\
\text { する. }\end{array}$ & 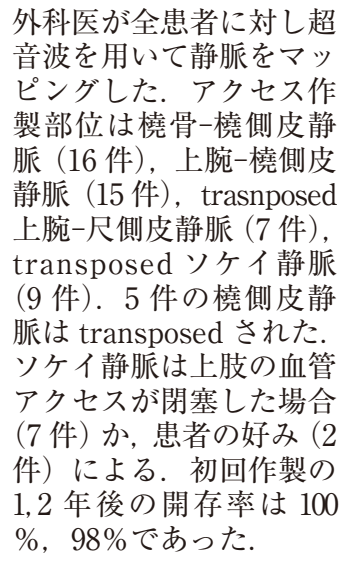 & $\begin{array}{l}\text { 自家血管を用いた } \\
\text { 透析アクセスは, } \\
\text { 術前の静脈マッピ } \\
\text { ング, 必要に応じ } \\
\text { た手術用顕微鏡の } \\
\text { 使用, 上肢アクセ } \\
\text { スが不可能ないし } \\
\text { 好まれないときに } \\
\text { ソケイ静 脈 の } \\
\text { transposed 使用 } \\
\text { を行うことですべ } \\
\text { ての小児に可能で } \\
\text { ある. }\end{array}$ \\
\hline 17 & $\begin{array}{l}\text { Tromp WF } \\
\text { Nephrol Dial } \\
\text { Transplant } \\
2012\end{array}$ & $\begin{array}{l}\text { オランダ, ベルギーの全 } \\
\text { 透析施設ならびに治療を } \\
\text { うけた患者 }\end{array}$ & $\begin{array}{l}\text { オランダ, ベルギーの } 9 \\
\text { 施設の治療方針と実際に } \\
\text { 実施された治療, ガイド } \\
\text { ラインの推奨とを比較す } \\
\text { る. 治療方針はアンケー } \\
\text { トで調査し, 実際に提供 } \\
\text { された治療とアウトカム } \\
\text { は } 2007 \text { 年から } 2010 \text { 年の } \\
\text { 期間に前向きで登録し } \\
\text { た. }\end{array}$ & 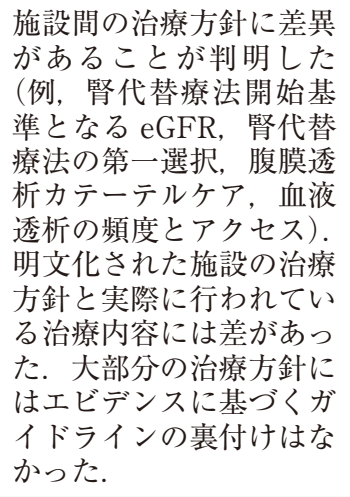 & $\begin{array}{l}\text { 小児に腎代替療法 } \\
\text { を提供する施設間 } \\
\text { には治療内容に大 } \\
\text { きな差があった. } \\
\text { 提供されたケアは } \\
\text { 施設の明文化され } \\
\text { た治療方針と一致 } \\
\text { しなが, 国際的 } \\
\text { に受け入れられて } \\
\text { いるガイドライン } \\
\text { が久如している. }\end{array}$ \\
\hline 18 & $\begin{array}{l}\text { Atkinson MA } \\
\text { Pediatr Nephrol } \\
2010\end{array}$ & $\begin{array}{l}1995 \text { 年から } 2002 \text { 年の期 } \\
\text { 間に新規透析䆃入となっ } \\
\text { た USRDS に登録された } \\
\text { 年 齢 1 1 } 18 \text { 歳の患者 } \\
4,772 \text { 名 }\end{array}$ & $\begin{array}{l}\text { 透析導入時の } \mathrm{eGFR} \text { 予 } \\
\text { 測因子, 高血圧や肺水腫 } \\
\text { での入院との関連を検討 } \\
\text { する. }\end{array}$ & 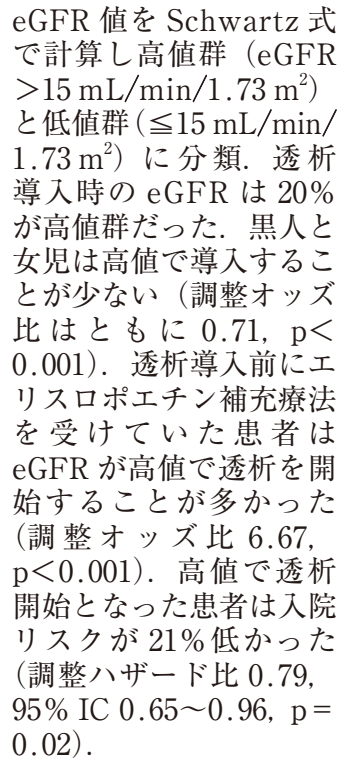 & $\begin{array}{l}\text { これらの臨床的利 } \\
\text { 益が心血管疾患に } \\
\text { よる死亡率, 合併 } \\
\text { 症率の低下につな } \\
\text { がるかどうかは不 } \\
\text { 明である. }\end{array}$ \\
\hline
\end{tabular}




\begin{tabular}{|c|c|c|c|c|c|}
\hline 22 & $\begin{array}{l}\text { 本多貴実子 } \\
\text { 日児腎誌 } \\
2012\end{array}$ & $\begin{array}{l}2005 \text { 年 } 6 \text { 月から } 2010 \text { 年 } \\
6 \text { 月に東京女子医科大学 } \\
\text { 腎臟小児科で腎代替療法 } \\
\text { を開始した } 15 \text { 歳以下の } \\
\text { 低異形性腎の症例 }\end{array}$ & $\begin{array}{l}\text { 腎代替療法の種類, 開始 } \\
\text { 時期, 開始時検査所見, } \\
\text { 開始直前の予期しない入 } \\
\text { 院イベントを診療録を用 } \\
\text { いて後方視的に検討. } \\
\text { 透析開始群と先行的腎臓 } \\
\text { 移植群で比較. }\end{array}$ & 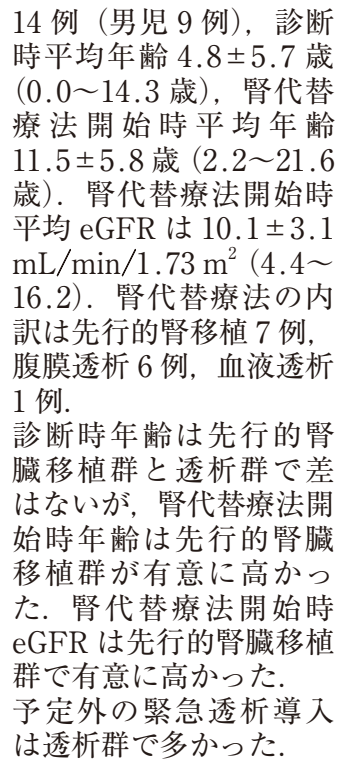 & $\begin{array}{l}\text { 無症候でも eGFR } \\
\text { が } 10 \mathrm{~mL} / \mathrm{min} / 1.73 \\
\mathrm{~m}^{2} \text { 前後になった } \\
\text { ら透析を開始する } \\
\text { のが安全である. }\end{array}$ \\
\hline
\end{tabular}

\section{文献}

1) Haffner D, Nisel R. Growth and puberty in chronic kidney disease. In : Geary DF and Schaefer F, eds. Comprehensive Pediatric Nephrology. Philadelphia : Mosby, 2008 ; 709-32.

2) Wesselin-Perry K, Salusky IB. Chronic Kidney Disease Mineral and Bone Disorder. In : Avner ED, Harmon WE, Niaudet P, Yoshikawa N, eds. Pediatric Nephrology. Heidelberg : Springer, 2009 ; 1755-83.

3) Kraut JA, Madias NE. Consequence and therapy of the metabolic acidosis of chronic kidney disease. Pediatr Nephrol $2011 ; 26: 19-28$.

4) Goodman WG, Goldin J, Kuizon BD, et al. Coronary-artery calcification in young adults with end-stage renal disease who are undergoing dialysis. N Engl J Med $2000 ; 342: 1478-83$.

5) Schroff RC, Donald AE, Hiorns MP, et al. Mineral metabolism and vascular damage in children on dialysis. J Am Soc Nephrol $2007 ; 18: 2996-3003$.

6) Lilien MR, Groothoff JW. Cardiovascular disease in children with CKD or ESRD. Nat Rev Nephrol 2009; $5: 229-35$.

7）日本透析医学会. 社団法人日本透析医学会 慢性腎臟病に伴う骨・ミネラル代謝異常の診療ガイド. 透析会誌 $2012 ; 45$ ： 301-56.

8) Menon S, Valentini RP, Kapur G, et al. Effectiveness of a multidisciplinary clinic in managing children with chronic kidney disease. Clin J Am Soc Nephrol $2009 ; 4: 1170-5$.

9) van Stralen KJ, Tizard EJ, Jager KJ, et al. Determinants of eGFR at start of renal replacement therapy in paediatric patients. Nephrol Dial Transplant $2010 ; 25: 3325-32$.

10) VanDeVoorde RG, Warady BA. Management of Chronic Kidney Disease. In : Avner ED, Harmon WE, Niaudet P, Yoshikawa N, eds. Pediatric Nephrology. Heidelberg : Springer, 2009 ; 1661-92.

11）岡田一義, 大平整爾，伊丹儀友，他．慢性血液透析療法の導入と終末期患者に対する見合わせに関する提言（案)。透析 会誌 $2012 ; 45: 1090-5$.

12) Chand DH, Valentini RP, Kamil ES. Hemodialysis vascular access options in pediatrics : considerations for patients and practitioners. Pediatr Nephrol $2009 ; 24: 1121-8$.

13) Zaritsky JJ, Salusky IB, Gales B, et al. Vascular access complications in long-term pediatric hemodialysis patients. Pediatr Nephrol $2008 ; 23: 2061-5$.

14) Gradman WS, Lermer G, Mentster M, Rodrigues H, Kamil ES. Experience with autogenous arteriovenous access for hemodialysis in children and adolescence. Ann Vasc Surg $2005 ; 19: 609-12$.

15) National Kidney Foundation. KDOQI clinical practice guidelines and clinical practice recommendations for 2006 update : hemodialysis adequacy, peritoneal dialysis adequacy, and vascular access. Am J Kidney Dis 2006 ; 48:S176-S322.

16）日本透析医学会. 2011 年版社団法人日本透析医学会「慢性血液透析用バスキュラーアクセスの作製㧍よび修復に関する ガイドライン」. 透析会誌 $2011 ; 44: 857-937$.

17) Tromp WF, Schoenmaker N, van der Lee JH, et al. Important differences in management policies for children with endstage renal disease in the Netherlands and Belgium-report from RICH-Q study. Nephrol Dial Transplant 2012; 27 : 1984- 
92.

18) Atkinson MA, Oberai PC, Neu AM, et al. Predictors and consequences of higher estimated glomerular filtration rate at dialysis initiation. Pediatr Nephrol $2010 ; 25: 1153-61$.

19) European Best Practice Guidelines for hemodialysis Part 1. Nephrol Dial Transplant 2002 ; 17 (Suppl 7) : S1-S111.

20) Rees L, Feather S, Schroff R. Haemodialysis clinical practice guidelines for children and adolescents. British Association for Paediatric Nephrology, 2008.

21) European Best Practice Guidelines for Peritoneal Dialysis. Nephrol Dial Transplant 2005 ; 20 (Suppl 9) : ix3-ix7.

22）本多貴実子, 秋岡裕子, 菅原典子, 他. 低・異形成腎に対する腎代替療法の選択と開始時期の検討. 日児腎誌 $2012 ； 25$ ： 1-4. 